University of Nebraska - Lincoln

DigitalCommons@University of Nebraska - Lincoln

July 2000

\title{
BLACK LEGISLATIVE POLITICS IN MISSISSIPPI
}

Byron D. Orey

borey2@unl.edu

Follow this and additional works at: https://digitalcommons.unl.edu/poliscifacpub

Part of the Political Science Commons

Orey, Byron D., "BLACK LEGISLATIVE POLITICS IN MISSISSIPPI" (2000). Faculty Publications: Political Science. 5.

https://digitalcommons.unl.edu/poliscifacpub/5

This Article is brought to you for free and open access by the Political Science, Department of at DigitalCommons@University of Nebraska - Lincoln. It has been accepted for inclusion in Faculty Publications: Political Science by an authorized administrator of DigitalCommons@University of Nebraska - Lincoln. 


\section{BLACK LEGISLATIVE POLITICS IN MISSISSIPPI ${ }^{*}$}

\author{
BYRON D'ANDRA OREY ${ }^{+}$ \\ University of Mississippi
}

T $\mathrm{n}$ the words of the old Negro preacher, "We ain't where we 1 ought to be, we ain't where we wanna be, but thank God we ain't where we used to be."

The Voting Rights Act of 1965 dramatically increased the number of Black legislators in the state of Mississippi. Prior to the passage of the Voting Rights Act, African Americans had not served in the Mississippi state legislature since 1896. However, by 1988, 22 African Americans gained seats in the state legislature. In this descriptive analysis, the evolution, nature of the membership, and substantive impact of the Mississippi Legislative Black Caucus are assessed.

Minority voting research has been categorized as occurring in four generations (Davidson \& Grofman, 1994). According to Davidson and Grofman (1994), first generation research questions evaluate minority enfranchisement. Second generation questions are concerned with vote dilution and the election of minority candidates. Furthermore, the authors introduced third and fourth generation questions that address the substantive gains made by African American elected officials. ${ }^{1}$ The research

" Published in JOURNAL OF BLACK STUDIES, Vol. 30, No. 6 (July 2000), pp. 791-814. @ 2000 Sage Publications, Inc. Used by permission.

+ Author's note: The author extends special thanks to Lisa Davis, Deputy Clerk for the House of Representatives, State of Mississippi, for her invaluable services. at hand places focus on third and fourth generation research questions.

The study proceeds with a historical overview of the election of Black legislators in the state of Mississippi. Secondly, a synopsis of the state's legislative process and the evolution of the Mississippi Legislative Black Caucus are given. Thirdly, the social background attributes of the African American legislators and the districts' characteristics of those African Americans who served between1970 and 1988 are examined. The analysis concludes by addressing the institutionalization of Black legislative participation and the impact of that participation on the links of the state's African American citizens.

\section{HISTORICAL OVERVIEW}

Arguably, the Voting Rights Act of 1965 has been the most effective civil rights legislation passed by the U.S. Congress. This legislation enabled African Americans to gain effective representation for the first time in the 20th century. As a result of Mississippi's infamous history of discrimination and racial terrorism against African Americans, it is one of seven states of the Old Confederacy to be completely covered by the Voting Rights special provisions. It is because of this complete coverage of the Voting Rights Act of 1965 that Mississippi has been able to increase its share of Black legislators.

Prior to the Civil War, African Americans were systematically excluded from the policy-making process in the state of Mississippi. The slave South possessed no Black officeholders, whereas the free states managed only token representation. The primary impetus contributing to the exclusion of African Americans from the political process revolves around Justice Roger B. Taney's opinion in the Dred Scott decision. ${ }^{2}$ In this decision, the Supreme Court ruled that people of African descent were not recognized as citizens of the United States. Southern Whites were strong supporters of this doctrine. Leading the charge 
against any federal intervention and a strong advocate of the preservation of state rights was the rebellious state of Mississippi. White racial dominance in the state of Mississippi was maintained via slavery and extralegal forces such as lynching and mobbing.

These extralegal forces notwithstanding, there existed a small vision of hope for African Americans in Mississippi and across the South. This hope lay in the period known as Reconstruction. Following the Civil War, Southern states were forced by the Military Reconstruction Act of 1867 to ratify new state constitutions with provisions granting male suffrage regardless of race. Moreover, the ratification of the Fifteenth Amendment in 1870 franchised Blacks by eliminating voter discrimination on the basis of "race, color, or previous condition of servitude." Most important, martial law was declared throughout the South, which resulted in the presence of federal troops in the region. Hence, the Reconstruction era served as the apex for African American empowerment in the aftermath of slavery.

During the 1867 and 1869 state legislative sessions, Mississippi witnessed the election of an astonishing 115 Black members to the state legislature (Foner, 1993). Thirteen Black members served in the Senate, whereas 102 were elected to the House (Foner, 1993). In addition, during the Reconstruction period, Alexander K. Davis was elected as lieutenant governor and John R. Lynch and Issac D. Shadd both served as speaker of the House. However, by the turn of the century, White conservatives nullified the political gains achieved by the state's African American citizens. In short, these gains would be short-lived, and it would take approximately 100 years before another African American would serve in the Mississippi state legislature.

In 1965, after being disfranchised from the political process for nearly 100 years, African American citizens in Mississippi were once again given a vision of hope. This hope is best characterized by what C. Vann Woodward (1965) coined as the "Second Reconstruction. "One of the most effective vehicles adopted during this era was the Voting Rights Act of 1965. However, immediately following the passage of the Voting Rights Act, White legislators began to stage massive resistance to dilute the potential gains of the Voting Rights Act. Unlike the first reconstruction, racial terrorism was not the predominant means of White resistance. Instead, White politicians adopted more subtle stratagems in their efforts to offset the impact of the Voting Rights Act. Among the strategies adopted to dilute the African American vote were gerrymandering and racial bloc voting. Such strategies are best explained by Chandler Davidson in his definition of dilution. According to Davidson(1984), vote dilution occurs when election laws or practices, coupled with racial bloc voting, diminish the voting strength of at least one group. These strategies proved to be successful in undermining the impact of the African American vote.

\section{THE MAKING OF A BLACK LEGISLATOR}

In 1967, despite the covert operations adopted by White legislators, Black voters coupled with White liberals were able to elect the first Black legislator since Reconstruction. Robert Clark, a schoolteacher in Holmes County, became the first Black this century to be elected to the Mississippi state legislature when he defeated J. P. Love, the White incumbent and chair of the House Education Committee. Clark's election was a by-product of the Voting Rights Act of 1965 combined with the strong mobilization efforts of local leaders and organizations, particularly the Mississippi Freedom Democratic Party (MFDP). The events leading to the election of Clark are an integral part of the history of Black legislators in the state of Mississippi. Thus, a brief synopsis of these events is detailed next.

The MFDP, a product of the Student Nonviolent Coordinating Committee and the first statewide independent Black political party in the South in recent times, was organized in response to the exclusion of African American citizens from state Democ- 
ratic Party affairs (Dittmer, 1994). The Black political mobilization for the 1967 elections had its roots in the Mississippi civil rights movement. The two major Black political organizations leading the efforts of registration drives and candidate endorsements were the National Association for the Advancement of Colored People(NAACP) and the MFDP. However, these two organizations operated under different political philosophies. According to a source quoted in Dittmer (1994), the NAACP was running candidates in the primaries because that camp believed that political power could be gained within the structure of the Mississippi Democratic Party. The MFDP supporters, on the other hand, maintained that the only way African Americans could gain political power was to develop an independent Black political force (see, e.g., Parker, 1990, pp.69-71). Consequently, the MFDP offered an independent slate of candidates, whereas the NAACP ran their candidates under the Democratic ticket. Thirty-two Black candidates in eight counties followed the strategy of the MFDP and ran as independents; all but one of the counties were in the Mississippi Delta. The strongest MFDP effort was in majority-Black Holmes County, where a slate of Black candidates contested 11 offices. Needless to say, the immediate impact of the Voting Rights Act was marginal, and Robert Clark of Holmes County emerged as the lone Black victor in the state legislature. In the 1967 elections, although African Americans constituted approximately $28 \%$ of registered voters in the state of Mississippi, Black candidates won only about $1 \%$ of the offices(Parker, 1990).

For 9 years, the massive resistance of White legislators diluted the ability of Blacks to elect legislators of their choice. However, in1976, Clark was joined by schoolteacher Doug Anderson, pastor/assistant school principal Horace Buckley, and civil rights attorney Fred Banks, all of Jackson, Mississippi. Thus, from 1968 to1979, African Americans received only token representation in the state legislature (Parker, 1990; Parker \& Phillips, 1981).However, in April 1978, a major breakthrough occurred.
The state was forced to change its election scheme from multimember districts to single-member districts as a result of previous litigation and a Section 5 objection by the Department of Justice. The litigation, initially filed as Connor v. Johnson in October of 1965 by the MFDP, served as one of the longest running legislative reapportionment cases in the history of American jurisprudence (Parker,1990). ${ }^{4}$ This case was continuously litigated for an amazing 14years, including nine visits before the Supreme Court, before the state's African American citizens were finally granted relief in1979. This policy intervention proved to be the savior for the African American electorate. After the change from multimember districts to single-member districts, African American voters were able to move from four Black elected legislators to 17 by 1980 .Hence, the change from multimember districts to single-member districts almost single-handedly explains the increase in Black legislators. Indeed, the research of Grofman, Migalski, and Noviello(1986) clearly documents the relationship between low levels of African American representation and multimember districts in Southern legislatures. (See Table 1 for a list of Mississippi Black legislators from 1970 to 1988.)

\section{STRUCTURE OF THE MISSISSIPPI STATE LEGISLATURE}

The Mississippi state legislature convenes in Jackson, Mississippi. The regular session of the legislature convenes on the first Tuesday following the first Monday in the month of January. Each regular session is 90 days long with the exception for the first year of a new term when it lasts 125 days.

The constitution places the legislative authority in a bicameral body comprising a Senate and a House of Representatives. As of 1988, this body consisted of 52 senators and 122 representatives. The representatives and senators are elected to 4-year terms. These terms expire at the end of the 4 -year period. 
TABLE 1

Black Elected Legislators in the Mississippi State Legislature (1970 to 1988)

\begin{tabular}{|c|c|c|c|}
\hline Member & Chamber & Party & Tenure \\
\hline \multirow[t]{2}{*}{ Robert Clark } & House & Independent & 1967 \\
\hline & & Democratic & 1972 to present \\
\hline \multirow[t]{2}{*}{ Doug Anderson } & House & Democratic & 1976 to 1980 \\
\hline & Senate & Democratic & 1980 to 1992 \\
\hline Fred Banks & House & Democratic & 1976 to 1985 \\
\hline Horace Buckley & House & Democratic & 1976 to 1992 \\
\hline Henry Kirksey & Senate & Democratic & 1980 to 1987 \\
\hline Credell Calhoun & House & Democratic & 1980 to 1992 \\
\hline Tyrone Ellis & House & Democratic & 1980 to present \\
\hline Hillman Frazier & House & Democratic & 1980 to present \\
\hline Isiah Fredericks & House & Democratic & 1980 to present \\
\hline David L. Green & House & Democratic & 1980 to present \\
\hline Clayton P. Henderson & House & Democratic & 1980 to present \\
\hline Aaron Henry & House & Democratic & 1980 to present \\
\hline Leslie D. King & House & Democratic & 1980 to present \\
\hline Barney Schoby & House & Democratic & 1980 to present \\
\hline Charles Shepphard & House & Democratic & 1980 to present \\
\hline Percy Watson & House & Democratic & 1980 to present \\
\hline Charles Young & House & Democratic & 1980 to present \\
\hline Edward Blackmon & House & Democratic & $\begin{array}{l}1979 \text { to } 1980, \\
1984 \text { to present }\end{array}$ \\
\hline Arthur Tate & Senate & Democratic & 1979 to 1980 \\
\hline Mitchell Ellerby & House & Democratic & 1984 to present \\
\hline Alyce Clarke & House & Democratic & 1985 to present \\
\hline Alice Hardin & Senate & Democratic & 1987 to present \\
\hline Alfred Walker, Jr. & House & Democratic & 1987 to present \\
\hline
\end{tabular}

SOURCE: Mississippi Secretary of State Office (1969, 1973, 1977, 1981, 1985).

The legislature in the state of Mississippi serves as the epitome for what was once known as the one-party South. As of 1988, Mississippi maintained the lowest percentage of Republican legislators than any other state in the South (Parker, 1990). In 1979 , only $2.3 \%$ of the state legislators were Republican (Southern Legislative Conference, as cited in Parker, 1990). After the change from multimember districts to single-member districts, this percentage barely increased to $9.8 \%$, still the lowest among the Southern states(Southern Legislative Conference, as cited in Parker, 1990).

Black legislators have generally secured seats in the state legislature under the auspices of the Democratic Party. In fact, with the exception of Robert Clark in 1967 and Doug Anderson in 1976, all of the Black elected legislators ran on the Democratic ticket.

According to Mary Coleman (1993) in her assessment of the legislative body in Mississippi, among the 29 standing committees in the House, 9 are "extremely powerful." The author suggest that the major legislative committees in Mississippi are Rules, Apportionment, Agriculture, Appropriations, Banks and Banking, Education, Judiciary A, Judiciary B, and Ways and Means.

\section{FORMATION OF THE MISSISSIPPI LEGISLATIVE BLACK CAUCUS}

The Mississippi Legislative Black Caucus evolved as an informal organization in 1976. This organization remained informal from 1976 to 1979. This developmental pattern is consistent with that of racial legislative caucuses in other states. Walton (1985) noted that African American legislators worked together on an ad hoc basis before formally organizing as a racial legislative subgroup. The early members included Representatives Robert Clark, Horace Buckley, Fred Banks, and Doug Anderson. In addition to these four Black legislators, a current representative and then House staff person, Hillman Frazier, joined in the discussion of strategies and tactics to enact their proposed legislation. In fact, according to former Representative Horace Buckley (personal communication, April 20, 1996), in the first years, Frazier was the only informal staff member that the caucus had. Frazier worked as a volunteer for the organization. In addition to Frazier, the caucus used Representative Robert Clark's (vice chair of the Education Committee) secretary. ${ }^{5}$ As of today, the caucus does 
not have a paid staff; however, they do receive support from volunteers, and they hire consultants on an as-needed basis.

In 1980, after an increase to 19 African American legislators, the caucus was formally established. According to former Representative and current State Supreme Court Justice Fred Banks (personal communication, June 10, 1995), the caucus grew out of a December 1979 seminar for the newly elected African American legislators. This meeting, sponsored by the Political Science Department of Jackson State University, marked the first time that all of the African American legislators were acquainted. Later that month, the African American legislators met at a local insurance agent's, Matt Thomas, house where they formed a committee to host a gala and ceremony honoring the state's African American lawmakers.

The first chair of the organization was senior member Robert Clark, followed by Fred Banks as the second chair. In a separate swearing-in ceremony, Justice Reuben Anderson took the honors of swearing in the junior and senior Black members of the state legislature. Ironically, this ceremony was held at the historic capitol building, the same building in which Mississippi seceded from the union.

According to the original bylaws, the purpose of the caucus is

1. to serve as a forum for discussion of legislative measures introduced in the Mississippi legislature,

2. to develop and affect legislation that addresses the priority concerns of Mississippians,

3. to serve as a vehicle to cause and impact on policies and practices established by all agencies and departments of the Mississippi state government,

4. to provide a mechanism for informing the citizenry of Mississippi of bills and resolutions pending before the Mississippi legislature that have particular implications for the community.
Unlike most state legislative racial subgroups, the Mississippi Legislative Black Caucus does not limit its membership to African Americans. According to the bylaws,

Any person who holds elective office as a state senator or a state representative in the Mississippi Legislature and who has a demonstrated commitment to the cause of equitable opportunity for black citizens of this state, shall be eligible to become a member of the Caucus. (Mississippi Legislative Black Caucus, n.d., p. 2)

The caucus is supported by the Political Education and Economic Development Foundation. This foundation was created by the caucus to provide financial support for the goals and objectives prescribed by the caucus. This foundation was also formed to meet the guidelines of a 501-C3 nonprofit organization. This status enabled the organization to receive financial support from business entities in compliance with federal tax regulations. The first chair of this foundation was Representative Charles Young. One of the main fund-raising events of the foundation is an annual banquet in which the proceeds are used to fund scholarships for students attending historically Black colleges and universities in the state of Mississippi. In addition, funds raised from the banquet financed political education forums sponsored by the caucus (H. Frazier, personal communication, May 13, 1995).

\section{NATURE OF BLACK LEGISLATORS AND LEGISLATIVE DISTRICTS}

Table 2 demonstrates that those African American members who served in the Mississippi legislature from 1970 to 1988 possessed similar characteristics to their White colleagues. As of 1988, the mean age for African American legislators was 48 compared to 45 for their White counterparts. Both groups possessed high lev- 
els of formal education. Approximately $56 \%$ of Black legislators received postbaccalaureate degrees, and $35 \%$ received college degrees. Approximately $9 \%$ of the Black legislators were noncollege graduates. On the other hand, an estimated $41 \%$ of White legislators received advanced college degrees, and $48 \%$ received a college degree. Approximately $11 \%$ of Whites were noncollege graduates. Overall, Black legislators were better educated than their White peers.

The high presence of lawyers in the Mississippi state legislature is consistent with the framework introduced by Keefe and Ogul (1985). Among African Americans participating in the state legislature, $29 \%$ of them were employed in the legal profession. Such percentages are comparable to those of White lawyers, who constituted $33 \%$ of the White legislators. Furthermore, whereas $23 \%$ of the African American legislators consisted of educators, only $7 \%$ of the White legislators were educators. In addition, only $4 \%$ of African American legislators were employed in the agricultural industry, whereas $21 \%$ of Whites worked in agricultural-related positions. According to Keefe and Ogul (1985), the field of business is another leading indicator for legislative participation. The percentage of Black businessmen serving in the legislature was comparable to the percentage of White businessmen. Of the Black legislators examined in this analysis, $13 \%$ were businessmen. White businessmen, on the other hand, occupied $14 \%$ of the seats held by White legislators.

In 1985, Alyce Clarke, a nutrition coordinator with the Jackson-Hinds Comprehensive Health Center, became the first Black woman elected to the state legislature. In 1987, Clarke was followed by Alice Hardin, a schoolteacher, as Hardin became one of the first African American women in the South to be elected to a state Senate. Similarly, whereas Black women constituted $9 \%$ of the Black elected legislators, White women made up $8 \%$ of the White elected legislators.
TABLE 2 Selected Characteristics of Black State
Legislators in Mississippi (1970 to 1988)

\begin{tabular}{lcc} 
Characteristic & Black Legislators & White Legislators \\
\hline Age (Mean in years) & 48 & 45 \\
Gender & & \\
$\quad$ Male & $91 \%$ & $92 \%$ \\
$\quad$ Female & $9 \%$ & $8 \%$ \\
Education & & \\
Advanced college & $56 \%$ & $41 \%$ \\
College graduates & $35 \%$ & $48 \%$ \\
Noncollege graduates & $9 \%$ & $11 \%$ \\
Occupation & & \\
Law & $29 \%$ & $33 \%$ \\
Business & $13 \%$ & $14 \%$ \\
Education & $23 \%$ & $7 \%$ \\
Clergy & $6 \%$ & $1 \%$ \\
Agriculture & $4 \%$ & $21 \%$ \\
Insurance & $0 \%$ & $7 \%$ \\
Medicine & $6 \%$ & $1 \%$ \\
Other & $19 \%$ & $16 \%$ \\
\hline
\end{tabular}

SOURCE: Mississippi Secretary of State Office $(1969,1973,1977,1981$, 1985).

Among the Black legislators, only 1 had been elected to a political office prior to joining the state legislature. Representative Barney Schoby served as a county supervisor for Adams County prior to being elected as a state legislator.

As of 1988, all of the African Americans elected to the state legislature were elected from predominantly Black districts. As mentioned earlier, following the court's decision in Connor, the state's African American citizens significantly increased their representation in the state legislature. This increase was primarily a function of the creation of majority-Black districts. As of 1988, 9 years following the adoption of single-member districts, the majority of Black legislators were elected from districts with 
at least 65\% Black population (Parker, 1990). Indeed, out of the 23 African American legislators who served in the Mississippi legislature from 1970 to 1988, 16 were elected from districts containing more than $65 \%$ Black population and at least $60 \%$ Black voting age population (Parker, 1990). Grofman and Handley (1991) notes that districts containing at least 60\% Black population are more apt to elect a Black legislator. ${ }^{6}$

These findings support the $65 \%$ rule of thumb adopted in Mississippi redistricting cases. Whereas a majority is normally computed as $50 \%$ plus $1 \%$ of the votes cast, in the state of Mississippi, the Black population percentage of a district must be increased by $5 \%$ for voting age population disparities, $5 \%$ for registration disparities, and an additional $5 \%$ for turnout disparities; thus, at $65 \%$, the Black electorate will have an equal opportunity to elect the candidate of his or her choice (Parker, 1990).

According to Table 3, on average, districts occupied by African American legislators contained approximately $68.8 \%$ African American population compared to the state average of $36 \%$ (Lilley, Defranco, \& Diefenderfer, 1994). In addition to these districts being predominantly Black in population, they deviated considerably from the state demographic averages as a whole. The average household income in Black districts was \$20,831 compared to the state average of $\$ 26,855$ (Lilley et al., 1994). Finally, only $15.7 \%$ of the population from the Black legislators' districts obtained a college education, whereas the average percentage for the state as a whole was $20 \%$ (Lilley et al., 1994). The earlier mentioned disparities accentuate the burdens and expectations of the African American legislative delegation in the state.
TABLE 3

Selected Socioeconomic Characteristics of Mississippi's Legislative Districts Represented by Black State Legislators

\begin{tabular}{lcr}
$\begin{array}{l}\text { Socioeconomic } \\
\text { Characteristic }\end{array}$ & $\begin{array}{c}\text { Mississippi Black } \\
\text { Legislative Caucus Districts }\end{array}$ & $\begin{array}{c}\text { State } \\
\text { Average }\end{array}$ \\
\hline Percentage Black Population & 68.8 & 36 \\
Household income & $\$ 20,831$ & $\$ 26,855$ \\
Percentage with college education & 15.7 & 20 \\
\hline
\end{tabular}

SOURCE: Lilley, Defranco, and Diefenderfer (1994).

\section{INSTITUTIONAL POWER POSITIONS}

As mentioned earlier, Coleman (1993) suggested that among the2 9 standing committees in the House, 9 are "extremely powerful." More important, prior to 1988, all committee assignments were made by the speaker of the house. ${ }^{7}$ According to Representative Hillman Frazier (personal communication, May 13, 1995), Black legislators were systematically excluded from "money committees"(e.g., Appropriations and Ways and Means committees) because of the perception that they were "spend and tax liberals." Parker (1990) states, "[House Speaker Buddy] Newman singlehandedly determined the fate of bills by manipulating their assignment to particular committees, determining their position on the House calendar, and timing floor actions" (p. 130). Consequently, during the 1987 session (by a vote of 75 to 45), Blacks coalesced with progressive Whites to dilute the powers of the speaker of the house. This victory was a result of a revolt against the house leadership, staged by progressive Whites and the Black legislators. Embedded in the new legislation was language that established seniority as a determinant for committee assignments. This led to the ousting of House Speaker Buddy Newman, marking the decline of the old guard leadership. 
TABLE 4

Black Committee Chairs in the Mississippi Legislature (1970 to 1988)

\begin{tabular}{lll} 
Member & Type of Committee & Tenure \\
\hline Hillman Frazier & Library & 1984 to present \\
Charles Shepphard & University and Colleges & 1984 to 1988 \\
Horace Buckley & Penitentiary $^{\text {a }}$ & 1984 to 1988 \\
Fred Banks & Judiciary En Banc $^{\text {a }}$ & 1984 to 1988 \\
& Ethics & 1980 to 1984 \\
Robert Clark & Judiciary B & 1984 to 1988 \\
& Education & 1976 to 1980 \\
& Education & 1980 to 1988
\end{tabular}

SOURCE: Mississippi Secretary of State Office (1969, 1973, 1977, 1981, 1985).

a. Vice chair.

Since gaining access to the state legislature, African American members have acquired seats on influential legislative committees. In 1976, Robert Clark became the first African American to serve as a vice chairman of any committee when he was appointed vice chairman of the Education Committee. In 1980, Clark and Fred Banks shared the honor of becoming the first Black legislators to serve in the capacity of chair of a committee. Clark was elevated to the position of chairman of the Education Committee, whereas Banks was appointed as the chairman of the Ethics Committee. Moreover, as indicated in Table 4, in 1984, Hillman Frazier became the chairman of the Library Committee, Charles Shepphard became the chairman of the University and College Committee, and Horace Buckley became vice chairman of the Penitentiary Committee.

\section{SUCCESS AND NATURE OF LEGISLATION INITIATED BY BLACK LEGISLATORS}

Black legislators have played a vital role in the adoption of public policy in the state of Mississippi. They have been especially instrumental in providing a swing vote to defeat or enact legislation. One such case occurred in 1986 when Black members were outraged over the decision in committee to defeat the Martin Luther King, Jr., holiday bill. As a result of the committee's decision, Black members of the House staged a weeklong filibuster that resulted in the death of approximately 120 bills (Davis, 1986). Consequently, the Martin Luther King, Jr., holiday bill was eventually passed in 1987. Such tactics have worked in favor of the Black caucus and have made way for compromise on other bills.

In 1983, Representative Fred Banks sponsored House Bill 649. This bill, coined as the Landlord-Tenant Law, was introduced to keep rental property affordable and the living conditions livable(Coleman, 1993). Banks introduced a version of this bill in each of the previous years that he had served in the legislature. However, in each of these years, the bill failed to gain passage. According to Coleman (1993), the issue of landlord tenancy was perceived to be a class-based issue with "racial underpinnings." This proposed bill served as a threat to the landowner market and was strongly lobbied against by a sizeable amount of White realtors. Needless to say, this bill failed to gain passage by the house.

However, Blacks were persistent in their efforts to pass this bill, and finally in 1990, after 14 years of unsuccessful attempts, this bill gained passage. According to Representative Frazier (personal communication, May 13, 1995), the passage of this bill was a function of simple "hard ball" politics. After Representative Percy Watson was appointed as chair of the Judiciary A Committee, Blacks were able to use his position as a leveraging device. In other words, Blacks were in a better position to compromise with Whites.

Furthermore, Parker (1990), in his seminal book, Black Votes Count, provided an account of the types of success garnered by Black legislators. Based on extensive interviews, Parker concludes that 
Both black legislators and interested observers believe that the black membership of the Mississippi Legislature has made the legislature more responsive to black needs in the enactment of legislation for educational reform, the establishment of state financed kindergartens for the first time in the history of the state, improvements in the state education financing system, the enactment of salary increases for public school teachers, improvements in the provision of health care under Medicaid, and the blocking of an increase in the state sales tax. (p. 134)

Further evidence of the impact of Black legislators, as cited by Parker (1990), is disclosed from a 1986 interview with a White representative, Fred Dobbins. According to Representative Dobbins, "when it gets down to suspension bills that take a twothirds vote or revenue bills, their bloc vote definitely is a determining factor then"(Parker, 1990, p. 134).

\section{TABLE 5}

Legislative Activity of Black Legislators in the Mississippi Legislature (1987 to 1988)

1987

\begin{tabular}{lccc} 
Legislative Activity & Introduced & Passed & Passage Rate \\
\hline Black legislators & 166 & 20 & $12.0 \%$ \\
Control group & 281 & 80 & $28.5 \%$ \\
\hline
\end{tabular}

1988

\begin{tabular}{lccc} 
Legislative Activity & Introduced & Passed & Passage Rate \\
\hline Black legislators & 285 & 15 & $5.0 \%$ \\
Control group & 238 & 49 & $21.1 \%$ \\
\hline
\end{tabular}

SOURCE: Office of the Clerk $(1987,1988)$.
TABLE 6

Nature of Bills Sponsored by Black Members of the Mississippi State Legislature (1987 to 1988)

\begin{tabular}{|c|c|c|}
\hline Category & 1987 & 1988 \\
\hline Education & 56 & 45 \\
\hline Suffrage & 12 & 11 \\
\hline Welfare & 3 & 1 \\
\hline Taxation & 1 & 17 \\
\hline Health care & 10 & 6 \\
\hline Communication & 2 & 1 \\
\hline Gambling/alcohol & 5 & 10 \\
\hline Martin Luther King, Jr., holiday & 1 & 0 \\
\hline Economic and community development & 4 & 12 \\
\hline Business regulation & 0 & 10 \\
\hline Civil rights & 0 & 0 \\
\hline Insurance & 11 & 8 \\
\hline Administrative & 5 & 30 \\
\hline Natural resources & 3 & 5 \\
\hline Tourism & 2 & 4 \\
\hline Local government & 12 & 25 \\
\hline Licensing & 4 & 5 \\
\hline Housing & 3 & 3 \\
\hline Child care & 2 & 2 \\
\hline Real estate & 1 & 0 \\
\hline Courts/legal & 12 & 12 \\
\hline Law enforcement & 7 & 22 \\
\hline Labor & 4 & 0 \\
\hline Gaming & 1 & 4 \\
\hline Ethics & 2 & 4 \\
\hline International & 2 & 3 \\
\hline Public safety & 0 & 6 \\
\hline Agriculture & 0 & 6 \\
\hline Public utility & 1 & 0 \\
\hline Recognition & 0 & 33 \\
\hline Total & 166 & 285 \\
\hline
\end{tabular}

SOURCE: Office of the Clerk $(1987,1988)$. 
Whereas Parker (1990) provided anecdotal support for the effectiveness of Black legislators, he admits that "a complete answer to this question would require an analysis of votes on critical bills in each session of the legislature since 1979" (p. 134). Although this analysis does not examine the proposed bills dating back to 1979, an analysis of the legislative proposals from the 1987 to 1988 legislative sessions should prove instructive.

The substantive impact of Black legislators in Mississippi in the1987 and 1988 sessions can be further evaluated by examining the success and nature of the groups' legislative efforts. Table 5 compares the success of bills introduced by the Black legislators to those sponsored by a sample of White legislators. ${ }^{8}$

During the 1987 legislative session, Black legislators introduced 166 bills. Of these 166 bills, 20 were passed, resulting in a $12.0 \%$ passage rate. On the other hand, the comparison group introduced 281 bills, of which 80 were passed, indicating a $28.5 \%$ passage rate. The passage rate of the entire legislature was $19 \%$. Furthermore, whereas the nature of the bills introduced by Black legislators varied, Table 6 indicates that 56 of those bills were related to education. This high presence of education-related bills is not alarming given the high percentage of Black legislators employed as educators. Moreover, a great deal of the bills sponsored by Black legislators in 1987 was tailored for their constituents. As a result, a number of bills were introduced to enhance the living conditions of the poor and undereducated in their districts.

During the 1988 session, there was a sharp increase in the number of bills introduced by Black legislators in the state of Mississippi. This number increased from 166 in 1987 to 285 in 1988.However, Black legislators continued to struggle to enact their proposed policy issues. Out of the 285 bills introduced in 1988 , only 15 , or $5 \%$, of them were passed into legislation. Conversely, their White colleagues were much more successful in their endeavors to enact legislation (21.1\%). Although the number of bills proposed by the control group (238) was fewer than the number proposed by Black members of the legislature, the number passed (49) far exceeded the number passed by Black legislators (15). Furthermore, the overall passage of the House in 1988 was $20 \%$. In sum, during the 2 years examined in this analysis, the success of the control group closely resembled the success of the entire legislature. On average, the disparity between Black legislators and the control group for 1987 and 1988 is $16.3 \%$.

As far as the nature of the bills introduced by Black members in 1988, Blacks continued to introduce bills relating to education in large numbers, with 45 being introduced. In addition, there was an increase in the number of economic and development bills proposed by Blacks that were written within the context of affirmative action (e.g., set-aside programs). Out of the 12 bills introduced relating to economic and community development, 7 of them were written within the context of affirmative action. Among the 7 bills introduced, none of them passed. According to Representative Horace Buckley (1996), any time Blacks proposed progressive legislation that had significant amounts of substantive content, it would ultimately be challenged. Hence, as a strategy, Buckley indicated that Black legislators took significant information out of a particular bill and put it in amendments or tacked it on to other bills. Therefore, although the bill in its entirety may not have passed, there was a greater probability of a partial bill passing.

There are a number of possible reasons that Blacks may have been unsuccessful in their attempts to pass self-sponsored legislation. However, the most accurate account of such a phenomenon is best described by the chair of the Mississippi Legislative Black Caucus, Representative Barney Schoby, a progressive White legislator from Mississippi. In a National Public Radio interview (April1993), Barney Schoby implied that the interests of Black legislators in 1993, even after doubling their representation from $12 \%$ to $24 \%$, were defeated by every turn: 
There is an effort to send a message to us, and to Black Mississippians, that no matter what your numbers are in the legislature, we're going to still control things.... We no longer have the clout that we once had with those progressive Whites because they feel that they were betrayed [in the redistricting process], and in general they were.

Furthermore, in addition to Schoby's testimony, one of the few progressive Whites who survived the 1992 elections, Ayres Haxton, noted that the redistricting process meant that

You end up with radicalized White districts and radicalized Black districts, in which the White representatives don't have to take into consideration the needs and wants of the Black people in the state, and Black people don't have to take into consideration the needs and wants of the Whites because they represent such a small number of them that they don't have to cater to their interests to get elected. (Haxton, 1993)

Despite such constraints, as well as the contention that Blacks remain tangential to the policy-making process (Black \& Black, 1987), this analysis indicates that Black legislators in the state of Mississippi have made substantive gains in the policymaking process. Although the gains have been marginal, in the words of the old Negro preacher, "We ain't where we ought to be, we ain't where we wanna be, but thank God we ain't where we used to be!"

\section{CONCLUSION AND EPILOGUE}

The study provides an in-depth examination of Black legislative participation in the state, which covers an 18-year period ranging from 1970 to 1988. This longitudinal analysis lays the groundwork necessary for moving to the next level of inquiry.
The study discovers that in the main, Black legislators in Mississippi are fairly comparable to their White counterparts. On average, Black legislators were better educated than White legislators. However, in most of the study's selected social background attributes, the African American members serving from 1970 to 1988 mirrored their White colleagues of the 1987 to 1988 legislative sessions.

Moreover, Black representation skyrocketed from 1 member of the legislature in 1967 to 17 members by 1980 . These newly elected Black legislators collaborated in forming the Mississippi Legislative Black Caucus. This proliferation of Black legislators was due to the enforcement of Section 5 of the Voting Rights Act and the substitution of multimember districts with single-member districts.

Whereas Black and White legislators were fairly comparable with respect to their social backgrounds, the districts Blacks represented were extremely different from the average district in the state. On average, districts Black legislators represented were Blacker, poorer, and less educated than those of the state as a whole.

Blacks were constrained in their efforts to pass legislation sponsored by Black caucus members. Whereas White legislators were successful in passing $28.5 \%$ and $21.1 \%$ of their proposed legislation in 1987 and 1988, respectively, Black legislators struggled to pass only $12 \%$ and $5 \%$ of their proposed legislation. Compared to the overall passage rates of the entire legislature, $19 \%$ and $20 \%$, respectively, Whites were more consistent in their abilities to introduce successful legislation. Such findings are not surprising given that the electorate votes along polarized lines (i.e., Whites vote White, and Blacks vote Black). In other words, the polarized voting that occurs at the election polls appears to trickle down to the legislative process. Consequently, White legislators appear to be simply representing their constituency, and in doing so, they limit the power of the caucus in passing bills most related to its constituency. There exists anecdotal evidence 
where progressive White legislators and Black legislators coalesced to produce progressive legislation. However, these cases appear to be marginal with respect to bills introduced by Black legislators.

Overall, although the systematic analysis conducted here suggests that Black legislators were limited in their ability to pass self-sponsored legislation, anecdotal evidence suggests that the Mississippi Legislative Black Caucus was capable of influencing the legislative process with such efforts as swing votes, cosponsorship, and committee influence.

In 1992, the Black membership in the state legislature increased from $12 \%$ to $24 \%$. Due to this increase, Blacks have recently begun to gain key leadership roles in the state legislature. Of most significance is the appointment of Robert Clark as speaker pro tem of the Mississippi House. Clark is the first to hold a leadership position of this status since Issac D. Shadd of Vicksburg served as speaker of the House in 1874 to 1875 . Furthermore, with the expansion of representation in the state legislature, the number of African American committee chairs in the house doubled. The following appointments were made after 1988: George Flaggs, chair of the Labor Committee; Percy Watson, chair of the Judiciary A Committee; Charles Young, chair of the Universities and Colleges Committee; Ed Blackmon, chair of the Judiciary B Committee; and Charles Shepphard, vice chair of the Ways and Means Committee.

The earlier discussion provides an indication of symbolic progress for Black legislators in Mississippi. The increase in Black legislators can create one of two scenarios: It can enhance the polarization of voting that currently exists between Whites and Blacks (e.g., conflict or hostility) or it can create a more cooperative (e.g., racial harmony) environment between White and Black legislators. According to Representative Ferr Smith, the former rather than the latter scenario currently exists in the Mississippi state legislature. Smith (personal communication, April 18 , 1996) contends that race is a powerful cue: "Once Whites [legislators] see something that will benefit Blacks, they vote the other way. It's blatant!" On the other hand, Smith suggests that Blacks can provide effective leadership in the state legislature. Representative Smith indicated that the presence of Blacks on legislative committees and subcommittees is one example of the effectiveness of Black leadership. A case in point is the recent voting bloc of Black members ( 3 to 2 ) of a senate subcommittee in denying the governor's appointment of four White men to the state college board. Andy Kanengiser (1996) of the Jackson Clarion Ledger writes, " The senators have knocked [Governor] Fordice for overlooking Mississippi's diverse population" (p. A1).

Hence, it appears that the presence of Blacks on legislative committees and subcommittees increases their chance to achieve substantive representation. In sum, such strategies as adopted by Watson in the passage of the Landlord Tenant Act, coupled with the presence of Blacks on legislative committees and subcommittees, are necessary if Blacks are to be successful in passing future legislation.

\section{NOTES}

1. According to Pitkin (1967), substantive representation is present when an elected official represents the interest of his or her community. In addition, the author defined symbolic representation as being typified by the presence of officials with similar physical traits as an ethnic or gender group.

2. Dred Scott v. Sanford (1857).

3. The Fifteenth Amendment in full reads as follows:

Section 1. The right of citizens of the United States to vote shall not be denied or abridged by the United States or by any State on account of race, color, or previous condition of servitude. 
Section 2. The Congress shall have power to enforce this article by appropriate legislation.

4. Connor v. Johnson (1966).

5. As the vice chair of the Education Committee, Clark received the services of a secretary.

6. The racial composition of a jurisdiction is generally believed to have a large impact on the possible election of a Black candidate, and the Black population as a percentage of the total population is widely regarded as the strongest single predictor of Black candidate success(Engstrom \& McDonald, 1981).

7. Buddy Newman served as speaker of the House from 1976 to 1987.

8. A comparable size of randomly selected White legislators was used to compare with the Black caucus members. The members of the control group include: Donald S. Alford, Frank L. Ely, John Grisham, Jr., Ashley Hines, Tommy A. Horne, Ezell Lee, Cecil McCrory, Hubert S. McMillan, John M. Nipper, Dianne C. Peranich, Ray Rogers, Dorlos Robinson, Morris Lee Scott, Cecil L. Simmons, Gary Staples, Joe Taylor, J. B. Van Slyke, Jr., Robert E. Vince, Joseph L. Warren, Robert Warren Moak, Don Grist, and J. P. Compretta.

\section{REFERENCES}

Black, E., \& Black, M. (1987). Politics and society in the South. New Haven, CT: Harvard University Press.

Coleman, M. (1993). Legislators, law and public policy: Political change in Mississippi and the South. Westport, CT: Greenwood.

Connor v. Johnson, 279 F. Supp. 619 (S.D. Miss. 1966).

Davidson, C. (1984). Minority vote dilution. Washington, DC: Howard University Press.

Davidson, C., \& Bernard, G. (1994). Quiet revolution in the South: The impact of the Voting Rights Act, 1965-1990. Princeton, NJ: Princeton University Press.
Davis, D. (1986, February 15). Racial confrontation erupts in house. Jackson Clarion Ledger, p. A1.

Dittmer, J. (1994). Local people: The struggle for civil rights in Mississippi. Chicago: University of Illinois Press.

Dred Scott v. Sanford, 19 How. 393 (1857).

Engstrom, R., \& McDonald, M. (1981). The election of Blacks to city councils: Clarifying the impact of electoral arrangements on the seats/population relationship. American Political Science Review, 75, 344-354.

Foner, E. (1993). Freedom's lawmakers: A directory of Black office holders during Reconstruction. New York: Oxford University Press.

Grofman, B., \& Handley, L. (1991). The impact of the Voting Rights Act on Black representation in Southern state legislatures. Legislative Studies Quarterly, 16, 111-128.

Grofman, B., Migalski, M., \& Noviello, N. (1986). Effects of multi-member districts on Black representation in state legislature. Review of Black Political Economy, 14, 65-78.

Kanengiser, A. (1996, May 10). Fordice says race reason nominees rejected. Jackson Clarion Ledger, p. A1.

Keefe, W. J., \& Ogul, M. S. (1985). The American legislative process: Congress and the United States. Englewood Cliffs, NJ: Prentice Hall.

Lilley, W., III, Defranco, L. J.,\& Diefenderfer, W. M., III. (1994). The almanac of state legislatures. Washington, DC: Congressional Quarterly Inc.

Mississippi Legislative Black Caucus. (n.d.). By-laws. Jackson, MS: Author.

Mississippi Secretary of State Office. (1969). Official and statistical register, 1968-1972.Jackson, MS: Author.

Mississippi Secretary of State Office. (1973). Official and statistical register, 1972-1976.Jackson, MS: Author.

Mississippi Secretary of State Office. (1977). Official and statistical register, 1976-1980.Jackson, MS: Author. 
Mississippi Secretary of State Office. (1981). Official and statistical register, 1980-1984.Jackson, MS: Author

Mississippi Secretary of State Office. (1985). Official and statistical register, 1984-1988.Jackson, MS: Author.

Office of the Clerk, State of Mississippi House of Representatives. (1987). House journal index. Jackson, MS: Author.

Office of the Clerk, State of Mississippi House of Representatives. (1988). House journal index. Jackson, MS: Author.

Parker, F.R. (1990). Black votes count. Chapel Hill, NC: University of North Carolina Press.

Parker, F. R., \& Phillips, B.Y. (1981). Voting in Mississippi: A right still denied. Washington, DC: Howard University Press.

Pitkin, H. (1967). The concept of representation. Berkeley, CA: University of California Press.

Walton, H. (1985). Invisible politics. Albany, NY: State University of New York Press.

Woodward, C. V. (1965). From the first reconstruction to the second. Harper's, 127-133.

Byron D'Andra Orey is an assistant professor in political science at the

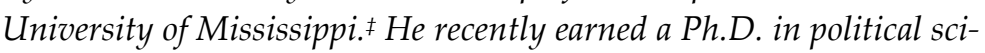
ence in August 1999 from the University of New Orleans. His scholarly publications have appeared in Southeastern Political Science Review and Social Science Quarterly.

$\ddagger$ Dr. Orey is currently (2006) in the Department of Political Science, University of Nebraska-Lincoln. 